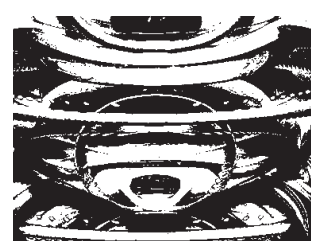

\title{
EUROPEIZACIJA HRVATSKOGA SUSTAVA AZILA: MEHANIZMI I INSTRUMENTI UTJECAJA EUROPSKE UNIJE NA JAVNE POLITIKE I INSTITUCIJE
}

Goranka LALIĆ NOVAK

Pravni fakultet, Zagreb

UDK: $341.43(4-6 E U: 497.5)$

$316.614-054.73(497.5)$

Pregledni rad

Primlieno: 9. 12. 2012.

Osnovna je svrha rada analiza mehanizama europeizacije i instrumenata kojima Europska unija utječe na javne politike država kandidatkinja za punopravno članstvo u Uniji, na primjeru sustava azila. Uz prikaz utjecaja EU-a na nacionalne sustave azila država koje su postale njezinim članicama prilikom tzv. istočnoga proširenja 2004. i 2007. godine, u radu se analiziraju instrumenti i mehanizmi procesa europeizacije hrvatskoga sustava azila. Istraživanje u radu provedeno je analizom domaće i strane literature o procesu europeizacije te zakonodavnih i drugih dokumenata donesenih u procesu pridruživanja RH Uniji. Na temelju analize izveden je zaključak kako se EU u odnosu na razvoj i mijenjanje hrvatskoga sustava azila služio istim instrumentima uvjetovanosti kao i prilikom istočnoga proširenja. Instrumenti europeizacije hrvatskoga sustava razlikuju se od ostalih zemalja Jugoistočne Europe uključenih u Proces stabilizacije i pridruživanja, za koje EU rabi dodatne instrumente utjecaja. $U$ vezi s mehanizmima europeizacije zaključuje se da je u odnosu na hrvatski sustav azila, uz uvjetovanost, do prijenosa europskoga modela došlo i dobrovoljno, odnosno socijalizacijom shvaćenom kao širenje i promiena normi i shvaćanja u procesima oponašanja i učenja.

Ključne riječi: europeizacija, azil, javne politike, politika uvjetovanosti, socijalizacija

Goranka Lalić Novak, Pravni fakultet Sveučilišta u Zagrebu, Trg maršala Tita 14, 10000 Zagreb, Hrvatska.

E-mail: goranka.lalic@pravo.hr 
Razvoj javnih politika imigracije i politike azila ${ }^{1}$ na razini Europske unije (EU) uključuje interes mnogih istraživača, no u odnosu na proučavanje utjecaja EU-a na nacionalne imigracijske politike nedostaje empirijskih istraživanja. Premda ovo područje postaje sve zanimljivije istraživačima, osjeća se "potreba za sveobuhvatnijim i komparativnim podacima kako bi se analizirao intenzitet europeizacije nacionalnih imigracijskih politika" (Ette i Faist, 2007, 5). Osim na politike država članica, EU utječe i na politike u državama koje nisu članice, a to žele postati. Naime, uz unutarnju harmonizaciju, javne politike EU-a transponiraju se i na države kandidatkinje za članstvo u Uniji, koje su obvezne uskladiti nacionalno zakonodavstvo s pravnom stečevinom EU-a te prilagoditi nacionalne upravne i sudske institucije za primjenu pravnih pravila u praksi. U pogledu država kandidatkinja govori se o europeizaciji kao uvjetovanosti, koja podrazumijeva promjene $\mathrm{u}$ kreiranju nacionalnih politika - upravo je uvjetovanost široko prihvaćena kao temeljna sastavnica politike EU-a prema državama nečlanicama u njezinu susjedstvu (Schimmelfennig i Sedelmeier, 2007, 89). U okviru politike uvjetovanosti, između ostalog, postavlja se pitanje kojim instrumentima EU utječe na javne politike država kandidatkinja te kako pod utjecajem procesa europeizacije dolazi do promjene na domaćoj razini. Ovo pitanje postavlja se posebno $u$ odnosu na imigracijske politike $u$ širem smislu, uključujući i politike azila, jer države imaju suvereno pravo kontrolirati svoje vanjske granice i ograničavati imigracije.

U skladu s navedenom konceptualizacijom problema, $\mathrm{u}$ radu će se analizirati instrumenti utjecaja EU-a na sustave azila država kandidatkinja, posebno onoga hrvatskog, te izvesti zaključak o načinima (mehanizmima) europeizacije. Glavno istraživačko pitanje rada jest utvrditi je li EU utjecao na hrvatski sustav azila koristeći se istim instrumentima utjecaja kao i prilikom istočnoga proširenja. Pritom je u radu analiza instrumenata utjecaja EU-a usredotočena na zakonodavnu razinu te na institucije uključene $u$ postupak utvrđivanja azilnoga statusa.

U teorijskom i praktičnom smislu, rad je doprinos proučavanju utjecaja EU-a na nacionalne javne politike i strukture država kandidatkinja za pridruživanje Uniji, ali i razumijevanju procesa razvoja sustava azila u Hrvatskoj.

U prvom dijelu postavlja se teorijsko-metodološki okvir rada, u drugom se dijelu prikazuje utjecaj EU-a na nacionalne azilne sustave prilikom istočnoga proširenja, a u trećem se analiziraju instrumenti utjecaja EU-a na hrvatski sustav azila. U zadnjem dijelu donose se zaključna razmatranja. 


\section{TEORIJSKO-METODOLOŠKI OKVIR RADA}

Neoinstitucionalno proučavanje utjecaja EU-a - europeizacija - kao novo područje istraživanja javlja se u drugoj polovini 1990-ih, i to zbog promjena u političkoj stvarnosti EU-a te zaokreta u teoriji i empirijskom fokusu (Koprić, Musa i Lalić Novak, 2012, 63). Proučavanje utjecaja EU-a konceptom europeizacije javlja se prije svega u odnosu na države članice EU-a, dok se proces europeizacije izvan granica Unije, točnije: $u$ državama kandidatkinjama za članstvo, počinje proučavati nešto kasnije, 2000-ih, kao istraživanja politike uvjetovanosti prilikom istočnoga proširenja EU-a. Proučavanje europeizacije u državama kandidatkinjama s vremenom se razvija kao posebno potpodručje u okviru teorije europeizacije, a recentno i kao pitanje učinaka europeizacije u novim državama članicama.

Općenito, pojam "europeizacija" rabi se kako bi se opisali fenomeni i procesi promjene. Šira definicija M. P. Vinka i P. Graziana $(2007,7)$ označuje europeizaciju kao "domaću prilagodbu na europsku regionalnu integraciju". Europeizacija se definira i kao proces oblikovanja, širenja i institucionalizacije formalnih i neformalnih pravila, stavova, procedura, policy paradigmi, stilova, načina ponašanja i zajedničkih stavova i normi koje se najprije definiraju i konsolidiraju u procesu donošenja EU odluka, a potom se ugrađuju u logiku domaćega diskursa, identitete, političke strukture i javne politike (Radaelli, 2000, 2003).

Težište europeizacije jest na nacionalnoj razini, pa europeizaciju treba razumijevati kao načine na koje institucije, procesi i politike s europske razine utječu na javne politike, politiku i političke zajednice na domaćoj razini - i država članica i nečlanica. U skladu s navedenim pristupom definiraju se i ključna istraživačka pitanja europeizacije: (a) što se mijenja dimenzije, područja europeizacije; (b) kako se mijenja - mehanizmi, načini europeizacije; (c) zašto se mijenja - učinci europeizacije (Sedelmeier, 2011).

Pod dimenzijama europeizacije razumijeva se utjecaj EU-a na javne politike (policy; funkcionalna dimenzija), na političke, upravne i druge strukture (polity; strukturna dimenzija izvršna, zakonodavna i sudska vlast, podnacionalna razina), međusobne odnose tih institucija, odnos države i društva, liberalna demokratska načela, kolektivni identitet te na političke procese (politics; procesna dimenzija - političke stranke, stranački sustav, interesne skupine) (Musa, 2009; Sedelmeier, 2011).

U odnosu na mehanizme europeizacije država kandidatkinja i nečlanica F. Schimmelfennig i U. Sedelmeier $(2004,2007)$ razlikuju nekoliko modela. Prvi je model "vanjskoga poticaja", izveden iz neoinstitucionalizma racionalnog izbora, u kojem je težište na asimetrijskoj moći pogađanja EU-a i zemalja kandidatkinja koja dovodi do usklađenosti u zamjenu za pomoć 
DRUŠ. ISTRAŽ. ZAGREB GOD. 22 (2013), BR. 2, STR. 237-256

LALIĆ NOVAK, G.: EUROPEIZACIJA... i integraciju, uz malen broj "veto igrača", koji su domaća zapreka za efikasnu politiku uvjetovanosti. ${ }^{2}$ Pri tome se uvjetovanost javlja kao demokratska uvjetovanost (obećanje pomoći ili članstva kao nagrade za demokratske promjene u skladu s temeljnim načelima EU-a) i kao uvjetovanost pravne stečevine (obveza preuzimanja pravila EU-a kao uvjet za napredovanje $\mathrm{u}$ pristupnim pregovorima). Drugi su modeli izvedeni iz sociološkog neoinstitucionalizma - model "socijalnog učenja" slijedi logiku prikladnosti i usredotočuje se na socijalizaciju državnih i nedržavnih aktera u odabranim zemljama, dok prema modelu "izvlačenja pouka" nezadovoljne vlade zemalja Jugoistočne Europe traže i preuzimaju prakse EU-a, a Unija pritom zauzima pasivnu ulogu. Pritom su mehanizmi europeizacije pod utjecajem faktora na razini EU-a i na nacionalnoj razini, a kao posebno važni nameću se preciznost zahtjeva EU-a te stupanj političke volje i institucionalnoga kapaciteta da se provede određena politika (v. više Musa, 2009, 238-241).

U istraživanjima europeizacija može biti ovisna ili neovisna varijabla, ovisno o razini analize. Kao ovisna varijabla rabi se $u$ istraživanju utjecaja država i njihovih preferencija na sam proces europeizacije, dok se kao neovisna primjenjuje $u$ istraživanjima utjecaja europeizacije na upravljanje i državne strukture. Ovdje je europeizacija neovisna varijabla koja utječe na razvoj javnih politika i institucija u državama kandidatkinjama za članstvo u EU-u.

Istraživanje u ovom radu provedeno je analizom domaće i strane literature o procesu europeizacije te zakonodavnih i drugih dokumenata donesenih prilikom procesa pridruživanja Hrvatske EU-u, a u odnosu na promjene $\mathrm{u}$ azilnom zakonodavstvu i na institucionalnoj razini.

\section{ISTOČNO PROŠIRENJE EUROPSKE UNIJE I UTJECAJ NA AZILNE POLITIKE DRŽAVA KANDIDATKINJA}

Za razliku od ranijih proširenja, istočno proširenje Unije obilježeno je politikom uvjetovanosti, koja je, u usporedbi s državama članicama, značajno produbila utjecaj EU-a na oblikovanje nacionalnih javnih politika, a sam proces pristupanja doveo do veće konvergencije s pojedinim europskim modelima javnih politika, zbog sljedećih faktora: (a) brzine prilagodbe, jer su se, zbog procesa pristupanja, države kandidatkinje morale brže i više adaptirati od država članica; (b) društvenih okolnosti uzrokovanih transformacijom iz komunističkoga sustava i slabosti javne uprave, zbog čega su institucionalni otpori promjenama osjetno manji nego u državama članicama; (c) "asimetrije moći" - nemogućnosti sudjelovanja država kandidatkinja u procesima donošenja odluka koje trebaju prenijeti u nacionalni sustav i nemogućnosti "podizanja" vlastitih preferencija na razinu Unije, pa je promjena nametnuta "odozgo 
DRUŠ. ISTRAŽ. ZAGREB GOD. 22 (2013), BR. 2, STR. 237-256

LALIĆ NOVAK, G. EUROPEIZACIJA... prema dolje"; (d) posrednoga širenja utjecaja EU-a i izvan "obveza iz članstva", uključivanjem u pretpristupne kriterije postojanje funkcionalnoga tržišnog gospodarstva i "sposobnosti nošenja s tržišnim silama unutar Unije" (Grabbe, 2006, 42-44; Sedelmeier, 2011, 6).

Europeizacija država kandidatkinja razlikuje se od europeizacije u državama članicama EU-a u pogledu instrumenata što ih rabe institucije EU-a u procesu prilagodbe - budući da ne postoji mogućnost sankcioniranja države kandidatkinje na temelju Osnivačkih ugovora, institucije EU-a koriste se "mekšim mjerama" (politikom uvjetovanosti, normativnim pritiskom i uvjeravanjem), a proces približavanja dugotrajan je i postupan, s naglaskom na usvajanje čitavog acquisa prije pristupanja, uz pojačane mehanizme nadzora i procjene napretka - napredak u fazama pristupanja neposredno je vezan uz ispunjenje specifičnih uvjeta, ciljeva i rokova (Grabbe, 2006). U tom se smislu instrumenti uvjetovanosti mogu sintetizirati u pet skupina: (a) modele - zakonodavne i institucionalne predloške - prikladne za preuzimanje pravne stečevine i usklađivanje s EU-regulacijama; (b) financijska sredstva - pomoć i tehnička potpora - koji su imali zamjetnu ulogu u transferu EU-modela; (c) sustavno vrednovanje (benchmarking) i praćenje - rangiranje zemalja kandidatkinja, postavljanje indikatora u pojedinim policy područjima i pružanje primjera dobre prakse kojima zemlje teže; (d) savjetovanje i "twinning" - ciljana upravna suradnja, koja uključuje privremeni premještaj službenika javne uprave zemlje članice kao savjetnika u određenom tijelu državne uprave partnerske zemlje; ${ }^{3}$ (e) tzv. čuvanje vrata pitanje mogućnosti započinjanja pregovora i pristup daljnjim fazama procesa pristupanja, ovisno o ispunjavanju uvjeta (Grabbe, 2003, 2006).

\section{Europeizacija nacionalnih azilnih politika - instrumenti i mehanizmi utjecaja EU-a}

U odnosu na pitanje azila, europeizacija tijekom i prije procesa pridruživanja u zadnja dva desetljeća znatno je utjecala na oblikovanje i transformaciju politike u zemljama kandidatkinjama (v. npr. Peshkopia, 2005; Byrne, 2002). Vanjsku dimenziju EU-suradnje u pitanjima pravosuđa i unutarnjih poslova (dalje: JHA), u okviru koje se nalazi i azilna politika, karakterizira, s jedne strane, suradnja sa zemljama podrijetla migranata i tranzitnim zemljama u odnosu na učinkovitije upravljanje granicama, suzbijanje krijumčarenja i trgovanja ljudima te ponovni prihvat migranata zatečenih u nezakonitom boravku na teritoriju EU-a, a s druge, poduzimanje preventivnih mjera za sprječavanje nezakonitog migriranja te stvaranje uvjeta za prihvat tražitelja azila na područjima zemljopisno bližima zem- 
DRUŠ. ISTRAŽ. ZAGREB GOD. 22 (2013), BR. 2, STR. 237-256

LALIĆ NOVAK, G.: EUROPEIZACIJA... jevanje procesa europeizacije politike azila $\mathrm{u}$ zemljama kandidatkinjama treba uzeti u obzir ove dvije dimenzije.

Politika azila postaje dijelom odnosa EU-a prema zemljama kandidatkinjama od sastanka Europskog vijeće u Essenu u prosincu 1994. - pritisak adaptacije prilikom procesa pristupanja, odnosno usklađivanja politika i zakonodavstva kao željenoga cilja - rezultirala je ubrzanjem procesa europeizacije sustava azila. Nastanak zajedničkoga prostora upravljanja migracijama reguliranog zajedničkim setom pravila u odnosu na nadzor vanjskih granica i azilni postupak ocrtava i teritorijalno jedinstvo Unije te govori u prilog postupnoj transformaciji EU-a iz "prvenstveno ekonomske tvorevine prema političkom akteru s vlastitim načelima i vrijednostima" (Lavenex i Uçarer, 2002, 2). Iz te perspektive može se zaključiti kako je europeizacija politike azila prihvaćanje i prijenos koncepata i politika u odnosu na azil razvijenih na razini EU-a na države nečlanice (top-down pristup).

Stvarni utjecaj europskih azilnih politika na zemlje nečlanice, a buduće kandidatkinje, vidljiv je prilikom istočnoga proširenja i prije započinjanja ugovornih odnosa s EU-om u dva pravca - $s$ jedne strane, i države nečlanice željele su oblikovati svoje sustave azila tako da se mogu smatrati prihvatljivim u svjetlu budućega podnošenja zahtjeva za članstvo, a s druge, provedbom migracijskih politika odgovarajućih onima u EU-u (Byrne, 2002, 382).

Nakon sloma komunističkih režima potkraj 1980-ih države kandidatkinje ubrzano su pristupale međunarodnim konvencijama i usvajale azilno zakonodavstvo kao odgovor na pojavu tražitelja azila. Rane azilne politike bile su mahom širokogrudnije od onih zapadno-europskih, jer države kandidatkinje nisu bile dovoljno svjesne utjecaja pristupanja EU-u na području azila i migracija te su pretpostavljale da je veći priljev tražitelja azila tek privremena i sporadična pojava ( $\mathrm{Phu-}$ ong, 2003, 649). Međutim, uskoro su države kandidatkinje morale prilagoditi svoje azilne politike onima u EU-u te usvojiti pravnu stečevinu EU-a o azilu (v. European Commission, 1997). Pitanje usklađenosti na području azila posebno je naglašeno u Europskim sporazumima, sklapanima sa svakom od država kandidatkinja, koji su sadržavali popis preporuka za usklađivanje nacionalnih politika s pravnom stečevinom EU-a. Pritom se, u razdoblju pristupanja ovih država kandidatkinja, europski model javne politike azila sastojao uglavnom od "soft law" dokumenata usmjerenih prema ujednačavanju nacionalnih praksi i neobvezujućih za države članice, koji su, međutim, za kandidatkinje bili obvezujući akti. Ubrzo nakon terorističkih napada 11. rujna 2001. neke od država kandidatkinja (Mađarska i Češka) usvojile su restriktivnije mjere od onih nužnih $\mathrm{u}$ procesu pristupanja - $\mathrm{u}$ odnosu na jači nadzor granice i suradnju s policijama i tajnim službama SAD-a i EU-a, a u 
DRUŠ. ISTRAŽ. ZAGREB GOD. 22 (2013), BR. 2, STR. $237-256$

LALIĆ NOVAK, G. EUROPEIZACIJA... strahu od mogućih posljedica od država članica (usporavanjem pristupanja ili stavljanjem veta na ulaz) te željom da pokažu ozbiljnost i predanost $\mathrm{u}$ pristupu JHA području (Grabbe, 2003, 314).

Budući da su azilni sustavi tranzicijskih zemalja koje su u punopravno članstvo EU-a ušle prilikom istočnoga proširenja u pravilu bili slabije razvijeni od onih zapadnoeuropskih, te su države prilikom procesa pristupanja bile ohrabrivane - a ponekad i prisiljene - da prilagode svoje standarde zaštite s onima EU-a. Pritom se restriktivne migracijske politike usmjerene na suzbijanje neregularnih migracija i smanjivanje broja tražitelja azila prenose i na zemlje kandidatkinje (v. npr. Lavenex, 2007; Peshkopia, 2005; Byrne, 2002), a pri "izvozu" migracijskih politika u načelu se ne poštuju posebne okolnosti i preferencije zemalja kandidatkinja (Jileva, 2002; cit. prema Peshkopia, 2005, 32), osim u odnosu na mogućnost uvođenja ili zadržavanja povoljnijih odredaba, a koja postoji u sekundarnom pravu EU-a. U tom smislu može se zaključiti kako je jedan od ciljeva politike uvjetovanosti u JHA području bilo uvjeriti države članice EU-a da će istočne članice biti slične državama Zapadne Europe te kako neće ugroziti stabilnost, demokratičnost i ekonomski razvoj EU-a (Grabbe, 2006, 37).

Usklađivanje s pravnom stečevinom i europskim standardima u procesu pristupanja u nekim je zemljama kandidatkinjama, čiji su sustavi bili znatno slabije razvijeni od onih u zemljama članicama, rezultiralo povećanjem standarda zaštite, osobito u odnosu na prihvat tražitelja azila i utvrđivanje statusa. U praksi je, međutim, usklađivanje najčešće težilo prihvaćanju najmanjih zajedničkih standarda, a politike su sve više zadobivale restriktivna obilježja. Granica "tvrđave Europe" pomaknuta je dalje na istok - pojava koju neki autori uspoređuju sa stvaranjem nove "željezne zavjese" (Phuong, 2003, 663).

Sumarno, na azilne politike država kandidatkinja prilikom istočnoga proširenja EU je utjecao sljedećim instrumentima: (a) eksplicitnim kriterijima utvrđenim 1997., koji uključuju pristupanje UN-ovoj Konvenciji o statusu izbjeglica i stvaranje potrebnih mehanizama za njezinu provedbu, usvajanje ostalih mjera iz pravne stečevine te posebnim nacionalnim uvjetima utvrđenim Europskim sporazumom, o čijem ispunjavanju ovise mogućnosti započinjanja pregovora i pristup daljnjim fazama procesa pristupanja; (b) savjetovanjem i ekspertnom pomoći, posebno u okviru projekta "Phare horizontalni program o azilu" pokrenutom 1998. u svrhu pružanja potpore u pripremi azilnoga zakonodavstva i njegovoj provedbi, a koji su u suradnji izvodili Europska komisija (dalje: EK), UNHCR i sedam država članica EU-a, a financirao EK u iznosu od 3 mil. eura (v. više Anagnost, 2001); (c) financijskim sredstvima predviđenim u okviru Phare-programa (nacionalnih i horizontal- 
DRUŠ. ISTRAŽ. ZAGREB GOD. 22 (2013), BR. 2, STR. $237-256$

LALIĆ NOVAK, G.: EUROPEIZACIJA... nih komponenti); ${ }^{4}$ (d) procjenom napretka u pregovorima koji od 1998. EK prati preko godišnjih izvještaja; (e) bilateralnom upravnom suradnjom između država kandidatkinja i članica EU-a koja je znatno utjecala na oblikovanje i provedbu azilnih politika u praksi, ovisno o pitanjima na koje je stavljen naglasak od strane partnerske države članice EU-a, 5 a koja je kasnije predstavljena kroz "twinning" projekte što ih financira EU (v. više Byrne, 2002).

U skladu s konceptualizacijom Schimmelfenniga i Sedelmeiera (2004, 2007), mehanizmi europeizacije politike azila država kandidatkinja prilikom istočnoga proširenja uključuju "vanjski poticaj", odnosno uvjetovanosti pravne stečevine, ali i model "socijalnog učenja" od država članica EU-a. Što se tiče faktora utjecaja na mehanizme europeizacije, istočno je proširenje obilježeno nepostojanjem jasnoga modela zajedničkoga europskog sustava azila na razini EU-a, odnosno, na razini država kandidatkinja, nedostatnim institucionalnim kapacitetima za primjenu politike azila $u$ praksi, manjkom praktičnog iskustva oko zbrinjavanja izbjeglica te nedostatnim javnim službama koje bi trebale biti uključene u proces njihove integracije na domaćoj razini, kao i nedovoljno razvijenim civilnim društvom koje bi moglo nadzirati tijela javne vlasti i zagovarati više standarde zaštite, ali istodobno i snažnom političkom voljom za pridruživanje EU-u i nedostatnim brojem i utjecajem "veto igrača" koji bi mogli dovesti u pitanje sam proces (v. Phuong, 2003; Byrne, 2002; Anagnost, 2001).

\section{EUROPEIZACIJA HRVATSKOGA SUSTAVA AZILA - PREGLED INSTRUMENATA UTJECAJA EUROPSKE UNIJE}

Procesi europeizacije zemalja kandidatkinja s područja Jugoistočne Europe, ${ }^{6}$ uključujući i Hrvatsku, obilježeni su tzv. kapacitetom apsorpcije EU,7 koji se smatra oslabljenim nakon ulaska dvanaest novih članica 2004. i 2007. Na razini potencijalnih članica, pristupanje EU-u jedan je od ključnih prioriteta nacionalnih politika, međutim, za razliku od istočnoga proširenja, kredibilitet politike uvjetovanosti smanjen je jer ne postoji tako jasna perspektiva članstva kao nagrade za poduzete promjene (cf. Trauner, 2009; Musa, 2009; Epstein i Sedelmeier, 2008; Schimmelfennig, 2008; Schimmelfennig i Sedelmeier, 2004).

\section{Institucionalizacija odnosa s Europskom unijom u okviru Procesa stabilizacije i pridruživanja}

Institucionalizacija odnosa RH s EU-om započela je sklapanjem Sporazuma o stabilizaciji i pridruživanju (2001; dalje: SSP), kojim je uspostavljen ugovorni odnos između RH i EU-a, a kao dio Procesa stabilizacije i pridruživanja (dalje: PSP) - dugoročne strategije EU-a prema tranzicijskim zemljama Jugoistočne Europe iz 1999. Perspektiva članstva u EU-u za ove zem- 
DRUŠ. ISTRAŽ. ZAGREB GOD. 22 (2013), BR. 2, STR. $237-256$

LALIĆ NOVAK, G. EUROPEIZACIJA... lje prvi je put izražena na sastanku Europskoga vijeća u Feiri u lipnju 2000., a kasnije ponovljena na sastancima u Kopenhagenu 2002. i Solunu 2003. Međutim, utjecaj EU-a, odnosno politika uvjetovanosti, razvija se i ranije - još polovinom 1990-ih, $\mathrm{u}$ okviru regionalne strategije usmjerene na pomirenje, obnovu i reforme, odnosno demokratizaciju i stabilizaciju zemalja regije i moguće sklapanje sporazuma o suradnji s EU-om.

$\mathrm{U}$ usporedbi s istočnim proširenjem, politika uvjetovanosti za zemlje Jugoistočne Europe u kontekstu PSP-a uključila je: (a) pretpristupne kriterije; (b) regionalni pristup EU-u iz 1997. i PSP; (c) posebne uvjete za svaku od zemalja prije sklapanja SSP-a; (d) uvjete koji proizlaze iz SSP-a i CARDS programa (Pomoć Zajednice za obnovu, razvoj i stabilizaciju); (e) uvjete povezane s pojedinim projektima i dodijeljenom pomoći, bespovratnim sredstvima i zajmovima; (f) uvjete koji proizlaze iz mirovnih sporazuma.

Paralelno uz PSP, EU je u lipnju 1999. inicirao donošenje Pakta o stabilnosti, političkoga dokumenta usmjerenog na razvoj dugoročne strategije za sprječavanja kriza na području Jugoistočne Europe i osiguranja stabilnosti u regiji, kroz pružanje potpore državama u jačanju demokracije, ljudskih prava i gospodarskog razvoja. Pakt postavlja okvir za suradnju država Jugoistočne Europe, drugih država, međunarodnih organizacija i raznih regionalnih inicijativa te je važan forum kojim je Unija utjecala na jačanje regionalne suradnje.

U području JHA utjecaj EU-a na Hrvatsku vidi se i prije PSP-a - 1990-ih RH je sklopila više readmisijskih sporazuma s državama članicama EU-a, prema kojima je obvezna prihvatiti državljane treće države ili apatride zatečene u nezakonitom prelasku državne granice ili nezakonitom boravku. Još važnije, na temelju uvjetovanosti EU-a, Hrvatska je poticana na sklapanje takvih sporazuma i sa zemljama regije, čime je mogućnost neprihvaćanja / vraćanja osoba kojima je potrebna međunarodna zaštita, $\mathrm{u}$ kontekstu upitne institucionalizacije prava na azil, osobito u djelovanju granične policije, znatno porasla. ${ }^{8}$

U odnosu na usklađivanje zakonodavstva s onim EU-a, već od početka 1999. postoji obveza poštivanja prava EU-a prilikom pripreme zakonodavstva, čime je stvorena osnova za harmonizaciju s pravnom stečevinom, bez obzira na to što takva obveza nije proizlazila iz (tadašnjih) odnosa RH s EU-om.

Suradnja na području viza, granične kontrole, azila i migracija, prema čl. 76. SSP-a, temelji se na međusobnim konzultacijama i uskoj koordinaciji te uključuje tehničku i upravnu pomoć u razmjeni informacija o zakonodavstvu i praksi, izradbi zakonodavstva, povećanju učinkovitosti tijela, izobrazbi osoblja i zaštiti putnih isprava i otkrivanju lažnih isprava. Suradnja je posebno usmjerena na izradbu i primjenu nacio- 
DRUŠ. ISTRAŽ. ZAGREB GOD. 22 (2013), BR. 2, STR. 237-256

LALIĆ NOVAK, G.: EUROPEIZACIJA... nalnoga zakonodavstva u skladu sa standardima UN-ove Konvencije o statusu izbjeglica, a radi osiguravanja poštivanja načela zabrane protjerivanja te pravednoga tretmana državljana drugih zemalja koji zakonito prebivaju na teritoriju kao i politiku integracije i osiguravanja prava i obveza usporedivih s onima vlastitih državljana. Nadalje, SSP-om je u čl. 69. navedena važnost usklađivanja postojećega hrvatskoga zakonodavstva sa zakonodavstvom Zajednice (tzv. harmonizacijska klauzula), a RH se obvezala postupno uskladiti postojeće i buduće zakonodavstvo s pravnom stečevinom Zajednice.

Prema planu provedbe SSP-a, do kraja 2001. trebalo je snimiti stanje zakonodavstva koje regulira područje kontrole granica, azila i migracija te izraditi nacrt prijedloga Zakona o azilu (dalje: ZoA); u prvoj polovini 2002. izraditi Nacionalni plan aktivnosti (dalje: NAP) u cilju razvoja i trajnoga stabiliziranja područja azila, migracija, granične kontrole i nadzora državne granice RH; do srpnja 2003. izraditi odgovarajuće provedbene propise na temelju ZoA. U navedenim aktivnostima nadležnom je hrvatskom tijelu (MUP) pomagala radna skupina u okviru Pakta o stabilnosti, sastavljena od predstavnika Njemačke i Slovenije kao članica "nacionalnoga tima" za pitanja azila.

Kao dio obveza RH preuzetih u okviru SSP-a 2001. u okviru MUP-a ustrojen je Odsjek za azil, dok je drugostupanjsko tijelo - Povjerenstvo Vlade RH za rješavanje žalbi tražitelja azila i azilanata - osnovano u prvoj polovini 2004., a članovi imenovani u kolovozu iste godine.

Prema mjesečnom izvještaju o ostvarivanju Plana provedbe SSP-a za siječanj 2002., nacrt prijedloga ZoA izrađen je i dostavljen na mišljenje drugim ministarstvima i Uredu za zakonodavstvo Vlade $\mathrm{RH}$, a kao rok za izradbu konačnoga teksta nacrta naznačen je ožujak 2002. Međutim, prema izvještajima za ožujak i travanj 2002., konačni tekst nije izrađen zbog usklađivanja pojedinih dijelova nacrta s pravnom stečevinom u skladu s preporukama stručnih timova država partnera iz projekta Pakta o stabilnosti, a rok je produljen na travanj, a zatim i lipanj 2002.

Na početku 2002. MUP je u okviru Pakta o stabilnosti, zajedno s partnerima iz Njemačke i Slovenije i uz sudjelovanje UNHCR-a, izradio NAP, u okviru kojeg su utvrđena područja na kojima je potrebno usklađivanje s pravnom stečevinom, a dokument je strateška osnova za restrukturiranje nadležnih tijela u kontekstu jačanja njihovih kapaciteta. Rezultati u NAP-u $\mathrm{u}$ pogledu komponente azila čine temelj za CARDS "twinning" projekt "Reforma azila", koji je započeo u siječnju 2003., u suradnji s partnerima - njemačkim Saveznim uredom za izbjeglice i slovenskim Ministarstvom unutarnjih poslova. Ukupni proračun projekta iznosio je 2,1 mil. eura, od čega je in- 
DRUŠ. ISTRAŽ. ZAGREB GOD. 22 (2013), BR. 2, STR. 237-256

LALIĆ NOVAK, G. EUROPEIZACIJA... vesticijski dio proračuna od 940000 eura bio namijenjen uređenju Prihvatilišta za tražitelje azila.

Nacrt ZoA usvojen je na sjednici Vlade RH 29. kolovoza 2002. i upućen u zakonodavnu proceduru, a donesen je 12 . lipnja 2003. Prema Nacionalnom programu RH za pridruživanje EU-u za 2004. stupanjem na snagu ZoA, "sustav azila u RH bit će uređen cjelovito i u skladu s relevantnim međunarodnim dokumentima".

Napredak u primjeni SSP-a preduvjet je za dobivanje statusa kandidata i otvaranje pretpristupnih pregovora, a prati ga EK kroz godišnje izvještaje. U tom smislu uvjetovanost "čuvanja vrata" snažno je naglašena u SSP-u, a sastoji se u usklađivanju postojećega hrvatskoga zakonodavstva na području azila i migracija s pravnom stečevinom EU-a, kao model reforme i prihvaćanja europskih vrijednosti i normi. Prilikom procesa pristupanja odnos EU-a i RH naglašeno je jednostran - Unija određuje pravila i uvjete koje RH mora zadovoljiti, a inače snosi sankcije u obliku usporavanja pristupnoga procesa.

\section{Politika azila u pretpristupnim pregovorima}

Na temelju zahtjeva za punopravno članstvo RH u EU-u, podnesenog u veljači 2003., Vijeće EU-a pozvalo je EK da izradi mišljenje (avis) o zahtjevu RH. Pozitivno mišljenje o zahtjevu RH doneseno je u travnju 2004., s preporukom o otvaranju pregovora o članstvu u EU-u, a pregovori su i formalno otvoreni u listopadu 2005. U odnosu na pitanje azila, EK navodi kako hrvatski azilni sustav ne sadrži ubrzan postupak ni koncepte "sigurne treće zemlje" i "očito neutemeljenog zahtjeva za azilom", posebnih instituta razvijenih u okviru EU-a (European Commission, 2004).

Istodobno s mišljenjem i preporukama, EK je donio i Prijedlog Europskoga partnerstva za Hrvatsku, s razrađenim kratkoročnim i srednjoročnim prioritetima, koje je Vijeće EU-a usvojilo u rujnu 2004. (Council of the European Union, 2004). Kratkoročni prioriteti, za 1-2 godine, na području azila uključuju provedbu novoga azilnog zakonodavstva i osnivanje Privremenoga centra za prihvat tražitelja azila. Međutim, već u izvještaju EK za 2005. navodi se potreba daljnjeg usklađivanja Zakona o azilu s pravnom stečevinom te drugi nedostaci hrvatskoga sustava azila (European Commission, 2005, 92-93). ${ }^{9} \mathrm{Na}$ temelju tog izvještaja, u Pristupnoj strategiji za RH (Council of the European Union, 2006), koju je Vijeće EU-a usvojilo na početku 2006., kao prioriteti na području azila navedeni su daljnje usklađivanje azilnoga zakonodavstva $s$ pravnom stečevinom i osnivanje trajnoga prihvatilišta za tražitelje azila (kratkoročno) te razvoj nacionalne baze osobnih 
DRUŠ. ISTRAŽ. ZAGREB GOD. 22 (2013), BR. 2, STR. 237-256

LALIĆ NOVAK, G.: EUROPEIZACIJA... ma za uključivanje $\mathrm{u}$ Eurodac i pojačane napore $\mathrm{u}$ integraciji izbjeglica (srednjoročno). Slično, i Izvještaj za 2006. navodi potrebu daljnjeg usklađivanja zakonodavstva s pravnom stečevinom EU-a o azilu, posebno u odnosu na ubrzani postupak, privremenu zaštitu i posebne postupke na granici, a kako bi se spriječilo daljnje nezakonito migriranje tražitelja azila (European Commission, 2006, 55). U skladu s navedenim, Nacionalnim programom pridruživanja RH Europskoj uniji za 2006. godinu $(2006,269)$ predviđeno je potkraj 2006. uputiti izmjene ZoA u zakonodavnu proceduru, a novi Zakon donesen je u lipnju 2007. Prema Izvještaju EK za 2007, novi ZoA usklađen je s pravnom stečevinom (European Commission, 2007, 52).

Izvještaji EK za 2008. i 2009. (European Commission, 2008, 2009) navode kako postoji potreba usklađivanja podzakonskih akata s pravnom stečevinom EU-a; izražavaju sumnju u neovisnost Povjerenstva za azil zbog utjecaja državnih tijela u postupku imenovanja članova; institucionalne kapacitete (prihvatilište za tražitelje azila) procjenjuju kao nedostatne; tumačenje azilnoga zakonodavstva procjenjuju kao vrlo strogo u pogledu prekršajnoga kažnjavanja tražitelja azila zbog nezakonitoga migriranja i, kao posljedicu, ograničavanje slobode kretanja; izražavaju zabrinutost zbog prakse ograničavanja osobnih saslušanja tražitelja azila u ubrzanom postupku te postavljaju pitanje integracije osoba kojima je priznat azilni status. Međutim, prema Izvještaju za 2010. navedeni nedostaci uglavnom su otklonjeni, a stupanjem na snagu izmjena i dopuna ZoA u srpnju 2010. "hrvatsko zakonodavstvo u potpunosti je usklađeno s pravnom stečevinom" (European Commission, 2010). Također, na inzistiranje EU-a, kao drugostupanjsko tijelo u postupku azila uveden je upravni sud, a poglavlje 24 privremeno je zatvoreno za pregovore na sjednici Međuvladine konferencije 22. prosinca 2010.

Zakonom o upravnim sporovima (NN 20/10, 143/12; dalje: ZuS) uspostavljen je novi dvostupanjski sustav upravnoga sudovanja, u okviru kojeg upravne sporove rješavaju četiri prvostupanjska upravna suda sa sjedištem u Zagrebu, Splitu, Osijeku i Rijeci10 te Visoki upravni sud kao drugostupanjski. Tijekom 2012. upravni sudovi odlučivali su u vijeću od tri suca, no izmjenama i dopunama ZuS-a iz prosinca 2012. promijenjena je odredba o sastavu suda te je određeno da u upravnim sporovima odlučuje sudac pojedinac, kako bi se povećala učinkovitost postupanja.

U praksi, postavlja se pitanje mogućnosti žalbe Visokom upravnom sudu na presudu upravnih sudova, jer upravnosudska praksa u primjeni tumači odredbu ZuS-a tako da je isključeno pravo žalbe Visokom upravnom sudu na odluku prvostupanjskoga upravnog suda u mnogim slučajevima. 
DRUŠ. ISTRAŽ. ZAGREB GOD. 22 (2013), BR. 2 STR. 237-256

LALIĆ NOVAK, G. EUROPEIZACIJA...

(1) TABLICA 1

Prikaz instrumenata utjecaja EU-a i učinak na hrvatski sustav azila

\begin{tabular}{lllll}
\hline Model & $\begin{array}{l}\text { Instrument } \\
\text { utjecaja EU-a }\end{array}$ & Izvor & $\begin{array}{l}\text { Zahtjev EU-a / } \\
\text { utjecaj instrumenta }\end{array}$ & $\begin{array}{l}\text { Odgovor na } \\
\text { domaćoj razini }\end{array}$ \\
\hline $\begin{array}{l}\text { Model } \\
\text { "vanjskoga } \\
\text { poticaja" }\end{array}$ & "Čuvanje & $\begin{array}{l}\text { Preporuke } \\
\text { vrata" }\end{array}$ & $\begin{array}{l}\text { Sklapanje readmisijskih } \\
\text { sporazuma. }\end{array}$ & $\begin{array}{l}\text { Sklopljeni sporazumi (Albanija, } \\
\text { Austrija, Benelux, Češka, Estoni- } \\
\text { ja, Francuska, BiH, Bugarska, } \\
\text { Crna Gora, Grčka, Island, Itali- } \\
\text { ja, Latvija, Litva, Mađarska, Ma- } \\
\text { kedonija, Norveška, Njemačka, } \\
\end{array}$ \\
& & $\begin{array}{l}\text { Poljska, Rumunjska, Slovačka, } \\
\text { Slovenija, Srbija, Švedska, Švi- } \\
\text { carska) }\end{array}$ \\
& & & \\
& & &
\end{tabular}

Budući da je novi sustav upravnoga sudovanja recentno reformiran, treba vidjeti kako će upravni sudovi odlučivati u azilnim predmetima - $\mathrm{u}$ smjeru potvrđivanja prakse MUP-a ili će pak razviti nove standarde zaštite tražitelja azila.

U procesu usklađivanja, budući da je već od samoga početka pregovora o pristupanju EU-u postojao osnovni model europske azilne politike sadržan u europskim direktivama usvojenim od 2001. do 2005., hrvatska su tijela imala jasan vodič za izradbu azilnoga zakonodavstva, s malom marginom vlastite interpretacije. Mogućnost usvajanja viših standarda od onih predviđenih pravnom stečevinom EU-a o azilu u načelu nije iskorištena, ${ }^{11}$ nego se usklađivanje provodilo samo na minimalne standarde zajamčene pravnom stečevinom, pa su u većini članaka ZoA doslovno prenesene odredbe iz relevantnih direktiva. Prilikom donošenja, zakonodavstvo o azilu nije izazvalo veće polemike u Hrvatskom saboru, a zakoni su usvojeni velikom većinom glasova zastupnika.

Osim u pogledu usklađivanja s pravnom stečevinom kao uvjetom za napredovanje u pregovorima i sustavnog vrednovanja, utjecaj EU-a vidi se i u suradnji s imigracijskim strukturama država članica. Tako je od 2007. do 2009. primijenjen CARDS "twinning" projekt "Reforma azila II", u suradnji s nizozemskim Uredom za imigraciju i naturalizaciju i mađarskim Uredom za imigraciju i državljanstvo, kako bi se "osiguralo da hrvatsko zakonodavstvo i postupci budu u skladu sa zakonodavstvom EU-a na području azila, dodatno razvio sustav azila na osnovi najboljih praksi zemalja članica EU-a te ojačala i unaprijedila učinkovitost državnih tijela u području azila". Nadalje, Hrvatska se uključuje u razne mreže i forume za raspravu, ${ }^{12}$ usmjerene na razvijanje suradnje, razmjenu prakse i konvergenciju nacionalnih sustava azila prema zajedničkom modelu.

$\mathrm{Na}$ temelju analize, instrumenti utjecaja EU-a na zakonodavnu i institucionalnu razinu hrvatskoga sustava azila mogu se pripisati mehanizmima "vanjskoga poticaja" $\mathrm{i}$ "socijalnog učenja" (v. Tablicu 1). 


\begin{tabular}{|c|c|c|c|c|}
\hline Model & $\begin{array}{l}\text { Instrument } \\
\text { utjecaja EU-a }\end{array}$ & Izvor & $\begin{array}{l}\text { Zahtjev EU-a / } \\
\text { utjecaj instrumenta }\end{array}$ & $\begin{array}{l}\text { Odgovor na } \\
\text { domaćoj razini }\end{array}$ \\
\hline & & $\begin{array}{l}\text { Sporazum o } \\
\text { stabilizaciji i } \\
\text { pridruživanju }\end{array}$ & $\begin{array}{l}\text { Donošenje azilnoga } \\
\text { zakonodavstva. } \\
\text { Usklađenost s među- } \\
\text { narodnim izbjegličkim } \\
\text { dokumentima. } \\
\text { Politika integracije. }\end{array}$ & $\begin{array}{l}\text { Zakon o azilu (2003). } \\
\text { Organizacijske promjene } \\
\text { u MUP-u. }\end{array}$ \\
\hline & & $\begin{array}{l}\text { Avis Europske } \\
\text { komisije }\end{array}$ & $\begin{array}{l}\text { Ubrzani postupak. } \\
\text { Sigurna treća zemlja. } \\
\text { Očito neutemeljen } \\
\text { zahtjev za azilom. }\end{array}$ & $\begin{array}{l}\text { Preuzimanje novih instituta } \\
\text { iz pravne stečevine. }\end{array}$ \\
\hline & & $\begin{array}{l}\text { Europsko } \\
\text { partnerstvo } 2004 .\end{array}$ & $\begin{array}{l}\text { Provedba azilnoga } \\
\text { zakonodavstva. Osni- } \\
\text { vanje Privremenoga } \\
\text { centra za prihvat traži- } \\
\text { telja azila. }\end{array}$ & $\begin{array}{l}\text { Podzakonski akti. Otvaranje } \\
\text { Prihvatilišta za tražitelje azila } \\
\text { u Kutini } 2006 \text {. }\end{array}$ \\
\hline $\begin{array}{l}\text { Model } \\
\text { "vanjskoga } \\
\text { poticaja" }\end{array}$ & Monitoring & $\begin{array}{l}\text { Godišnji izvještaji } \\
\text { Europske komisije } \\
\text { o napretku } \\
(2005 .-2011 .)\end{array}$ & $\begin{array}{l}\text { Usklađivanje Zakona o } \\
\text { azilu i podzakonskih } \\
\text { akata s pravnom } \\
\text { stečevinom. Provedba } \\
\text { azilnoga zakonodavstva } \\
\text { u praksi. Jačanje kapaci- } \\
\text { teta. Neovisnost drugo- } \\
\text { stupanjskoga tijela. } \\
\text { Politike integracije. }\end{array}$ & $\begin{array}{l}\text { Novi Zakon o azilu 2007., } \\
\text { izmjene i dopune iz } 2010 . \\
\text { Zapošljavanje i edukacija služ- } \\
\text { benika MUP-a. Promjene u sa- } \\
\text { stavu Povjerenstva za azil. } \\
\text { Uvođenje supsidijarne zaštite. } \\
\text { Pripreme za sudjelovanje u su- } \\
\text { stavima Dublin i EURODAC. }\end{array}$ \\
\hline $\begin{array}{l}\text { Model } \\
\text { "vanjskoga } \\
\text { poticaja" }\end{array}$ & $\begin{array}{l}\text { Sustavno vred- } \\
\text { novanje (bench- } \\
\text { marking) }\end{array}$ & $\begin{array}{l}\text { Zajedničko } \\
\text { stajalište EU-a } \\
\text { u poglavlju } 24 .\end{array}$ & $\begin{array}{l}\text { Pristup potpuno } \\
\text { funkcionalnom } \\
\text { postupku azila. }\end{array}$ & $\begin{array}{l}\text { Uvođenje upravnog suda kao } \\
\text { drugostupanjskog tijela. }\end{array}$ \\
\hline \multirow[t]{3}{*}{$\begin{array}{l}\text { Model } \\
\text { "vanjskoga } \\
\text { poticaja" }\end{array}$} & \multirow[t]{3}{*}{$\begin{array}{l}\text { Financijska } \\
\text { sredstva }\end{array}$} & CARDS program & $\begin{array}{l}\text { Jačanje kapaciteta. In- } \\
\text { vesticijske komponente: } \\
\text { Prihvatilište za traži- } \\
\text { telje azila; nabava op- } \\
\text { reme za Dublin i } \\
\text { EURODAC sustav. }\end{array}$ & \multirow[t]{3}{*}{ Potpora razvoju sustava. } \\
\hline & & TAIEX & Edukacija. & \\
\hline & & MATRA & $\begin{array}{l}\text { Jačanje kapaciteta za } \\
\text { EURODAC i Dublin } \\
\text { sustav. }\end{array}$ & \\
\hline \multirow[t]{2}{*}{$\begin{array}{l}\text { Modeli } \\
\text { "vanjskoga } \\
\text { poticaja" i } \\
\text { "socijalnog } \\
\text { učenja" }\end{array}$} & \multirow[t]{3}{*}{$\begin{array}{l}\text { Savjetovanje } \\
\text { i "twinning" }\end{array}$} & $\begin{array}{l}\text { CARDS I } \\
\text { Zemlje partneri: } \\
\text { Njemačka } \\
\text { i Slovenija }\end{array}$ & $\begin{array}{l}\text { Harmonizacija s prav- } \\
\text { nom stečevinom. Pro- } \\
\text { vedba zakonodavstva }\end{array}$ & $\begin{array}{l}\text { Zakon o azilu } 2003 . \\
\text { Razmjena iskustava - } \\
\text { socijalizacija. }\end{array}$ \\
\hline & & $\begin{array}{l}\text { CARDS II } \\
\text { Zemlje partneri: } \\
\text { Nizozemska i } \\
\text { Mađarska }\end{array}$ & $\begin{array}{l}\text { u praksi. Jačanje kapa- } \\
\text { citeta. Edukacija. }\end{array}$ & $\begin{array}{l}\text { Izmjene i dopune Zakona } \\
\text { o azilu iz 2010. Razmjena } \\
\text { iskustava - socijalizacija. }\end{array}$ \\
\hline \multirow{2}{*}{\multicolumn{2}{|c|}{$\begin{array}{l}\text { (1) TABLICA } 1 \\
\text { (nastavak s } \\
\text { prethodne stranice) }\end{array}$}} & GDISC & $\begin{array}{l}\text { Suradnja s imigracijskim } \\
\text { službama EU-a. }\end{array}$ & $\begin{array}{l}\text { Razmjena iskustava - } \\
\text { socijalizacija. }\end{array}$ \\
\hline & & TAIEX & Podizanje kapaciteta. & $\begin{array}{l}\text { Razmjena iskustava - } \\
\text { socijalizacija. }\end{array}$ \\
\hline
\end{tabular}


DRUŠ. ISTRAŽ. ZAGREB GOD. 22 (2013), BR. 2 STR. 237-256

LALIĆ NOVAK, G. EUROPEIZACIJA...
Što se tiče domaćih faktora koji su utjecali na mehanizme europeizacije, RH je imala iskustvo zbrinjavanja i zaštite izbjeglica i prognanika, ${ }^{13}$ no ne i stranaca iz trećih zemalja. Pravo na azil bilo je zajamčeno prvim Ustavom RH iz 1990., a na temelju sukcesije bivše SFRJ, RH je od osamostaljenja stranka Konvencije o statusu izbjeglica. ${ }^{14}$ Ustavna odredba razrađena je Zakonom o kretanju i boravku stranaca iz 1991., no zbog mnogih neusklađenosti s međunarodnim standardima i upitne provedbe $u$ praksi do donošenja ZoA ne može se govoriti o postojanju koherentnoga sustava azila.

Prvi zahtjevi za azil zabilježeni su 1997., a do 2010. broj tražitelja azila kretao se između 100 i 200 osoba na godinu. Od 2010. bilježi se znatan porast broja zahtjeva za azil (gotovo 1200 zahtjeva u 2012.).

Općenito, pitanje azila nije izazvalo prijepore i interes $u$ širem društveno-političkom diskursu, nego je tema od interesa samo u užoj stručnoj zajednici te nadležnom tijelu (MUP). Što se tiče organizacija civilnoga društva, dijalog između države i tih organizacija u Hrvatskoj ima skromnu tradiciju, a njihov utjecaj na javne politike slab je i ograničen (Bežovan, 2003, 138). Općenito, u Hrvatskoj je malo organizacija koje se sustavno bave politikom azila (v. Lalić Novak, 2010). Ključna "veto točka" - Hrvatski sabor - $\mathrm{u}$ razvoju sustava azila nije odigrao važniju ulogu, prije svega zbog toga što domaći (politički) troškovi adaptacije na zahtjeve EU-a nisu bili visoki, jer se radilo o pitanju koje nije predstavljalo problem $\mathrm{u}$ hrvatskom društvu ni u okolnostima maloga broja tražitelja azila, ali i stranaca općenito.

\section{ZAKLJUČNA RAZMATRANJA}

Na temelju analize u prethodnim dijelovima rada može se zaključiti kako se EU u odnosu na razvoj i mijenjanje hrvatskoga sustava azila koristio istim instrumentima utjecaja kao i prilikom istočnoga proširenja, ali s razlikom u pogledu postojanja jasnoga modela zajedničkoga europskog sustava azila, koji je razvijen 2000-ih godina. Međutim, za razliku od ostalih zemalja Jugoistočne Europe uključenih u PSP, EU u odnosu na Hrvatsku nije se koristio liberalizacijom viznog režima kao oblikom nagrade (ili "mrkve") za postignute reforme na JHA području. U tom smislu, proces europeizacije hrvatskoga sustava azila u pogledu instrumenata utjecaja sličniji je zemljama koje su u članstvo EU-a ušle prilikom istočnoga proširenja.

U odnosu na uvjete koji su utjecali na mehanizme europeizacije, domaći kontekst RH i država kandidatkinja istočnoga proširenja razlikuje se u pogledu iskustva u zbrinjavanju izbjeglica te postojanja normativnog uređenja njihove zaštite. Sličnost je, međutim, vidljiva u odnosu na (ne)postojanje, "veto točaka" i nedostatne institucionalne kapacitete za provedbu 
DRUŠ. ISTRAŽ. ZAGREB GOD. 22 (2013), BR. 2, STR. 237-256

LALIĆ NOVAK, G.: EUROPEIZACIJA...

\section{BILJEŠKE}

politike azila u praksi, uz istodobno postojanje snažne volje za pristupanje EU-u.

Snaga utjecaja EU-a uvjetovana je prije svega mogućnošću usporavanja pretpristupnoga procesa. U tom smislu, usporedbom indikatora vrednovanja uspjeha u prihvaćanju uvjeta EU-a i odgovorom hrvatskih tijela, može se zaključiti kako je hrvatski sustav azila, kao i sustavi država kandidatkinja prilikom istočnoga proširenja, usklađen s onima EU-a prije svega zbog očekivanoga napretka u pristupnim pregovorima, a ne intrinzičnoga shvaćanja prednosti europskoga modela. Međutim, zaključak o tome da je do preuzimanja europskoga modela azilne politike došlo isključivo nametanjem rješenja, a ne i socijalizacijom, upitan je. Naime, u Hrvatskoj je pristupanje EU-u najvažniji politički cilj od 2000. godine. Hrvatska je dobrovoljno uložila zahtjev za punopravno članstvo u EU-u i pristala na sve uvjete koji iz toga proizlaze. S druge strane, instrumenti utjecaja EU-a usmjereni na interakciju s državama kandidatkinjama u procesu proširenja, poput "twinning" projekata, znatno utječu na prijenos europskoga modela, a transnacionalne mreže koje povezuju države kandidatkinje i EU važan su faktor utjecaja Unije na domaćoj razini - kroz adaptacijski pritisak, ali i kao sredstvo uvjeravanja domaćih aktera u legitimitet europskih pravila (cf. Sedelmeier, 2011). Stoga je teško razdvojiti što je u razvoju sustava azila bilo posljedica zahtjeva EU-a, a što je usvojeno socijalizacijom kao prihvatljiv model upravljanja migracijskim tokovima (koji uključuju i tražitelje azila na domaćem teritoriju.

S obzirom na domaće specifičnosti koje Hrvatsku razlikuju od tranzicijskih zemalja koje su članicama EU-a postale prilikom istočnoga proširenja, postavlja se pitanje bi li se sustav azila u Hrvatskoj naposljetku morao razviti i bez utjecaja EU-a, zbog egzogenih (osoba koje traže zaštitu, pritiska međunarodnih organizacija) i endogenih faktora i institucija (pritiska domaćih institucija, preuzetih međunarodnih obveza). U tom slučaju, Hrvatska bi, moguće, razvijala vlastiti azilni sustav kroz model "socijalnog učenja", promjenom normi i shvaćanja kroz procese oponašanja i učenja drugih zemalja s razvijenim azilnim sustavima.

${ }^{1}$ Iako je riječ o raznim politikama, osobito u pogledu njihove pravne regulacije, poveznica između politika azila i migracija nalazi se $u$ konceptu mješovitih migracijskih kretanja, koja obuhvaćaju razne kategorije osoba - izbjeglice, tražitelje azila, ekonomske migrante, žrtve trgovanja ljudima - koje iz raznoraznih razloga napuštaju zemlje svojega podrijetla, kreću se i prelaze državne granice bez odgovarajućih dokumenata i ulaze u zemlje odredišta. Pritom migranti mogu zbog niza okolnosti biti istodobno u različitim ulogama te prelaziti iz jedne uloge $\mathrm{u}$ drugu, primjerice ekonomski migrant može postati izbjeglicom sur place zbog promjena u zemlji podrijetla, a 
DRUŠ. ISTRAŽ. ZAGREB GOD. 22 (2013), BR. 2 STR. $237-256$

LALIĆ NOVAK, G. EUROPEIZACIJA... odbijeni tražitelj azila, koji $u$ određenom roku ne napusti zemlju, postaje neregularnim migrantom. Također, imigracijska politika u dijelu upravljanja granicama i mjerama za sprječavanje neregularnih migracija utječe i na mogućnost pristupa teritoriju i sustavu azila zemlje odredišta.

2 Politikom uvjetovanosti smatra se situacija u kojoj međunarodna organizacija obeća nagradu (u obliku financijske pomoći ili primanja u članstvo) određenoj zemlji ako ispuni jedan uvjet ili više njih (poput usklađivanja politika ili institucionalnih promjena), što ih je utvrdila sama organizacija (Schimmelfennig i Sedelmeier, 2007, 88). Posebni kriteriji za pristupanje EU-u utvrđeni su u prvoj polovini 1990-ih, a obuhvaćaju političke, ekonomske, pravne i administrativne kriterije.

3 "Twinning" projekti usmjereni su na postizanje konkretnih operativnih rezultata u vezi s provedbom pravne stečevine ili javnih politika EU-a, a nakon završetka projekta uspostavljeni sustav treba biti funkcionalan i postati potpuna odgovornost države korisnice.

4 Od 1997. do 2001. države kandidatkinje su u okviru nacionalnih Phare-programa primile 13 mil. eura za projekte povezane s azilom, migracijama i viznom politikom.

5 Tako je u baltičkim državama kandidatkinjama kroz suradnju s nordijskim članicama EU-a naglasak stavljen na jačanje mjera kojima se onemogućuje pristup teritoriju, dok je u kandidatkinjama s područja Srednje i Jugoistočne Europe u žarištu bilo vraćanje migranata $\mathrm{u}$ treće zemlje na temelju readmisijskih sporazuma.

${ }^{6}$ Ovdje se podrazumijevaju sljedeće zemlje: Hrvatska, Makedonija, Crna Gora, Srbija, BiH i Albanija.

7 Apsorpcijski ili integracijski kapacitet označuje sposobnost EU-a da primi nove članice, ne ugrožavajući pritom mogućnost vlastite integracije.

$8 \mathrm{Uz}$ poticaj na sklapanje readmisijskih sporazuma, EU se poslužio još jednim instrumentom utjecaja - obećanom liberalizacijom svojega viznog režima u odnosu na zemlje Jugoistočne Europe, kao svojevrsnom nagradom za usklađivanje domaćih viznih režima, jačanje nadzora granice itd. (cf. Trauner, 2009). Međutim, za razliku od ostalih zemalja uključenih u PSP, Hrvatska nije stavljena na zajednički popis zemalja čijim je državljanima potrebna viza za ulazak na teritorij EU-a.

${ }^{9}$ Izvještaj navodi i pitanje transparentnosti, neovisnosti i profesionalnosti drugostupanjskoga tijela; osnivanja stalnog centra za tražitelje azila; jačanje kapaciteta Dokumentacijsko-informacijskog centra MUP-a; potrebu edukacije o azilu na svim razinama državnih tijela; razvoj baze osobnih podataka tražitelja azila; modernizaciju opreme. Također, u izvještaju se navodi kako se ne može ocijeniti provedba azilnoga zakonodavstva u praksi, jer niti jednom tražitelju azila nije odobren status.

10 Suci upravnih sudova imenovani su u studenom i prosincu 2011., od kojih je određen broj iz redova sudskih savjetnika Upravnoga suda RH.

11 Sporadično uvođenje viših standarda od onih predviđenih pravnom stečevinom, primjerice zdravstveno osiguranje i pravo na rad osoba pod supsidijarnom zaštitom, karakteristično je za recentne izmjene ZoA, odnosno stabilan sustav azila. 
DRUŠ. ISTRAŽ. ZAGREB GOD. 22 (2013), BR. 2, STR. 237-256

LALIĆ NOVAK, G.: EUROPEIZACIJA...

\section{LITERATURA}

12 Primjerice, suradnja u okviru GDISC (General Directors' of Immigration Services Conference), Srednjoeuropske policijske akademije (MEPA) itd. 13 U praksi su zaštita izbjeglica i provedba prava na azil odvojena na zakonodavnoj (različiti propisi koji ih uređuju, uvođenje termina "azilant" u ZoA kako bi se i terminološki odvojili pojmovi) i institucionalnoj razini (različita nadležnost).

14 UNHCR, kao agencija UN-a za zaštitu izbjeglica, u RH djeluje od 1991.

Anagnost, S. (2001). Challenges facing asylum systems and asylum policy development in Europe: Preliminary lessons learned from the Central European and Baltic states (CEBS). European Journal of Law Reform, 3(1), 29-49. doi:10.1093/ijrl/12.3.380

Bežovan, G. (2003). Utjecaj organizacija civilnog društva u Hrvatskoj. Revija za sociologiju, 34(3-4), 127-142.

Boswell, C. (2003). The "external dimension" of the EU immigration and asylum policy. International Affairs, 79(3), 619-638. doi:10.1111/ 14682346.00326

Byrne, R. (2002). Future perspectives: Accession and asylum in an expanded European Union. U R. Byrne, G. Noll i J. Vedsted-Hansen (Ur.), New asylum countries? Migration control and refugee protection in an enlarged European Union (str. 373-422). The Hague: Kluwer Law International.

Council of the European Union (2004). Council Decision 2004/648/EC of 13 September 2004 on the principles, priorities and conditions contained in the European partnership with Croatia, OJ L 297, 22. 9. 2004.

Council of the European Union (2006). Council Decision 2006/145/EC of 20 February 2006 on the principles, priorities and conditions contained in the accession partnership with Croatia and repealing decision 2004/ 648/EC, OJ L 55, 25. 2. 2006.

Epstein, R. A. i Sedelmeier, U. (2008). Beyond conditionality: International institutions in postcommunist Europe after enlargement. Journal of European Public Policy, 15(6), 795-805. doi:10.1080/135017 60802196465

Ette, A. i Faist, T. (2007). The Europeanization of national policies and politics of immigration: Research, questions and concepts. U A. Ette i T. Faist (Ur.), The Europeanization of national policies and politics of immigration: Between autonomy and the European Union (str. 3-31). New York: Palgrave Macmillan.

European Commission (1997). Agenda 2000: For a stronger and wider Europe, COM (97) 2000 final/1.

European Commission (2004). Communication from the Commission Opinion on Croatia's application for membership of the European Union, COM/2004/0257, 20. 4. 2004.

European Commission (2005). Croatia 2005 Progress Report, COM (2005) 561 final, 9. 11. 2005.

European Commission (2006). Croatia 2006 Progress Report, COM (2006) 649 final, 8. 11. 2006.

European Commission (2007). Croatia 2007 Progress Report, COM (2007) 663, 6. 11. 2007. 
DRUŠ. ISTRAŽ. ZAGREB GOD. 22 (2013), BR. 2 STR. $237-256$

LALIĆ NOVAK, G.: EUROPEIZACIJA...
European Commission (2008). Croatia 2008 Progress Report, COM (2008) 674, 5. 11. 2008

European Commission (2009). Croatia 2009 Progress Report, COM (2009) 533, 14. 10. 2010.

European Commission (2010). Croatia 2010 Progress Report, COM (2010) $660,9.11 .2010$.

Grabbe, H. (2003). Europeanization goes east: Power and uncertainty in the EU accession process. U K. Featherstone i C. M. Radaelli (Ur.), The politics of Europeanization (str. 303-327). Oxford: Oxford University Press. doi:10.1093/0199252092.003.0013

Grabbe, H. (2006). The EU's transformative power. Europeanization through conditionality in Central and Eastern Europe. Hampshire: Palgrave Macmillan.

Koprić, I., Musa, A. i Lalić Novak, G. (2012). Europski upravni prostor. Zagreb: Institut za javnu upravu.

Lalić Novak, G. (2010). Razvoj sustava azila u Hrvatskoj. Zagreb: Društveno veleučilište $\mathrm{u}$ Zagrebu.

Lavenex, S. (2007). Asylum policy. U P. Graziano i M. Vink (Ur.), Europeanization: New research agendas (str. 309-320). Basingstoke, Hampshire: Palgrave Macmillan.

Lavenex, S. i Uçarer, E. (2002). The emergent EU migration regime and its external impact. U S. Lavenex i E. Uçarer (Ur.), Migration and the externalities of European integration (str. 1-14). Oxford: Lexington Books.

Musa, A. (2009). Europeizacija i agencijski model javne uprave. (Doktorska disertacija). Pravni fakultet Sveučilišta u Zagrebu, Zagreb.

Nacionalni program RH za pridruživanje EU za 2004. Narodne novine 37/2004.

Nacionalni program RH za pridruživanje EU za 2006. (2006). Ministarstvo vanjskih poslova i europskih integracija, http://www.mvpei.hr/ ei/download/2006/04/13/NPPEU_-_2006.pdf (8. 11. 2012.).

Peshkopia, R. (2005). Asylum capacity building in the Balkans: A rational answer to leaders' concerns. Albanian Journal of Politics, 1(1), 26-54.

Phuong, C. (2003). Enlarging "fortress Europe": EU accession, asylum, and immigration in candidate countries. International and Comparative Law Quarterly, 52(3), 641-663. doi:10.1093/iclq/52.3.641

Radaelli, C. M. (2000). Whither Europeanization? Concept stretching and substantive changes. European Integration Online Papers, 4(8). http:// www.eiop.at/eiop (1. 3. 2012.).

Radaelli, C. M. (2003). The Europeanization of public policy. U K. Featherstone i C. M. Radaelli (Ur.), The politics of Europeanization (str. 27-56). Oxford: Oxford University Press.

Schimmelfennig, F. (2008). EU political accession conditionality after the 2004 enlargement: Consistency and effectiveness. Journal of European Public Policy, 15(6), 918-937. doi:10.1080/13501760802196861

Schimmelfennig, F. i Sedelmeier, U. (2004). Governance by conditionality: EU rule transfer to the candidate countries of Central and Eastern Europe. Journal of European Public Policy, 11(4), 661-679. doi:10. 1080/1350176042000248089 
DRUŠ. ISTRAŽ. ZAGREB GOD. 22 (2013), BR. 2, STR. 237-256

LALIĆ NOVAK, G. EUROPEIZACIJA...
Schimmelfennig, F. i Sedelmeier, U. (2007). Candidate countries and conditionality. U P. Graziano i M. Vink (Ur.), Europeanization: New research agendas (str. 88-101). Basingstoke, Hampshire: Palgrave Macmillan.

Sedelmeier, U. (2011). Europeanisation in new member and candidate states. Living Reviews in European Governance, 6(1). http://www. livingreviews.org/lreg-2011-1, (18. 3. 2012.).

Sporazum o stabilizaciji i pridruživanju. Narodne novine - Međunarodni ugovori 14/2001.

Trauner, F. (2009). From membership conditionality to policy conditionality: EU external governance in South Eastern Europe. Journal of European Public Policy, 16(5), 774-790. doi:10.1080/13501760902983564

Vink, M. i Graziano, P. (2007). Challenges of a new research agenda. U P. Graziano i M. Vink (Ur.), Europeanization: New research agendas (str. 3-20). Basingstoke: Palgrave Macmillan.

\section{Europeanization of the Croatian Asylum System: Mechanisms and Instruments of European Union Influence on Public Policies and Institutions}

\author{
Goranka LALIĆ NOVAK \\ Faculty of Law, Zagreb
}

The main purpose of the paper is to analyse the mechanisms of Europeanization and the EU instruments of influence on public policies of candidate countries, using the example of asylum policy. In addition to analysing the instruments and mechanisms of the Europeanization of the Croatian asylum system, the paper includes an overview of EU influence on the asylum policies of candidate countries during the EU Eastern enlargement in 2004 and 2007. The research is based on an overview of literature on Europeanization and legislative and other documents adopted during the process of Croatian accession to the EU. The results indicate that in the context of the Croatian asylum system, the EU used the same instruments of influence as during the Eastern enlargement. In this sense, the Europeanization instruments of the Croatian asylum system differ from those of the other Southeastern European countries also participating in the Stabilization and Accession Process, for which the EU uses additional instruments of influence. With regard to the mechanisms of Europeanization, it is concluded that the transfer of the European model, in addition to accession conditionality, has also been accepted voluntarily, by socialization understood as diffusion and change of norms and understanding throughout the process of imitation and learning.

Keywords: Europeanization, asylum, public policies, accession conditionality, socialization 